\title{
References
}

Elster, J. (1992) Local Justice. New York: Russell Sage Foundation. Walzer, M. (1977) Just and Unjust Wars. New York: Basic Books. Walzer, M. (1983) Spheres of Justice. New York: Basic Books. Walzer, M. (1988) The Company of Critics. New York: Basic Books. Walzer, M. (2004) Arguing About War. New Haven, CT: Yale University Press.

Chris Brown London School of Economics, London, UK

\section{Anarchism and authority: A philosophical introduction to classical anarchism}

\author{
Paul McLaughlin \\ Ashgate Publishing, Aldershot, 2007, 202pp., £55.00, ISBN: 978-0754661962
}

Contemporary Political Theory (2009) 8, 242-244. doi:10.1057/cpt.2008.54

McLaughlin's aim in this book is to re-define the relationship between anarchism and authority and correct what he believes is a misapprehension: that anarchism can be defined in terms of a rejection of the state or of authority 'as such'. Indeed, in the course of the book he argues that anarchists accept quite a lot of authority. For example, they typically accept parental authority and what he calls operative authority.

The book is organized in two parts. Thus the argument is not a philosophical analysis of the concept in classical anarchism, as the title implies. Rather it is first, an account of the concept of authority and second, an analysis of authority in three leading classical theorists: Godwin, Proudhon and Stirner.

The conceptual analysis is wide-ranging and premised on the notion of scepticism. Anarchist scepticism differs from other kinds (Pyrrhonian and Cartesian) because it is not used as a devise for revelation or the discovery of truth and because it is political or ethical rather than personalistic. Yet the important point, here, seems to be to provide a springboard for an analysis which relies heavily on liberal theory, principally critical liberalism of Joseph Raz and Leslie Green. It's not surprising, therefore, to find that McLaughlin finds that his treatment of anarchism might look like "no more than a radicalisation of liberalism' (p. 53). He denies that anarchism can in fact be represented in this way, but his approach undoubtedly encourages such a view. 
Authority is associated with command, binding commitment and the duty to obey. The definition McLaughlin prefers is Green's: authority provides a content-independent reason for action and exclusionary reasons for not acting (p. 57). Having spent some time arriving at this point, McLaughlin moves the analysis to types of authority. Operative authority - which anarchists, or at least all 'but the most extreme' accept - is a form of practical authority, described as a 'right of $A$ to issue practical directives and a correlative duty of $B$ to follow or to obey them' (p. 67). Specifically, following de George he argues it is the kind of authority that is 'exercised in freely formed groups' (p. 72). This definition does quite a lot of work since the claim that anarchists accept operative authority seems only to be based on the observation that anarchists advocate decentralized, cooperative forms of organization. If these are to work, they must accept authority - whatever they might say, or think to the contrary.

When it comes to the authority of the state, McLaughlin rehearses a number of arguments for legitimacy and discovers that anarchists find them all wanting. The result is that anarchists do indeed emerge as anti-statists. Still keen to substantiate his opening claim, McLaughlin qualifies his position to argue that anarchism cannot be defined 'simply' in terms of a rejection of the state and that anti-statism is only a 'central component of anarchism' which doesn't 'exhaust anarchist thinking' since there are other kinds of 'authoritative relations' - though clearly not parental relations - that anarchists wish to challenge (p. 97). His position seems remarkably close to Bakunin's antiauthoritarianism?

The second part of the book looks at what McLaughlin identifies as the foundational texts of anarchist political thought. McLaughlin admits that two of his three key thinkers did not identify themselves as anarchists but the inclusion of Godwin and Stirner makes good sense in terms of the interest in authority. What is disappointing in his treatment of these writers, however, is that the abstract claims made in the first half of the book are not used to structure the discussion. McLaughlin says that the point is to provide historical context; although it is abundantly clear that he is not trying to appeal to historians of political thought, it is not really obvious what is being contextualized. Indeed, his focus seems to shift quite radically as he sets out to demonstrate the left-Hegelian influences active on anarchist thought. This is an interesting, though contentious argument, especially with respect to Proudhon whose apparent failure to properly understand Hegel was one of the sticks with which Marx used to beat him. Yet the relationship between this discussion and the conceptual analysis is not entirely clear. The final sections of the book, which run through anarchists from Bakunin to Bookchin, give an indication of some of McLaughlin's broader concerns, but add little to the overall discussion. 
It seems that the sub-text of McLauglin's work is to rescue anarchism from its reputation for negativity; to show that anarchists have made an important and constructive contribution to political theory and that anarchism has equally important insights to offer to contemporary politics. One of the first things he does in the book is address the anarchists' reputation for violence. In the conclusion, he considers anarchism's social relevance. In these aims, McLaughlin follows a growing line of writers. But the force of the argument is sometimes lost in the exceptionally abstract approach he takes and the lofty tone he tends to adopt. For example, Saul Newman's equally positive contribution to contemporary anarchist theory is inexplicably dismissed before it is discussed (and then only very briefly). At one point, McLaughlin accuses Rorty of dogmatic assertion (p. 84). Yet most of what anarchists are said to believe in the first half of the analysis is almost entirely unsupported. McLaughlin suggests that philosophical rigour is needed to fill the gaps in anarchist thought that historians and political scientists have failed to fill. My impression is that the conclusions McLaughlin finally draws are quite familiar to readers of these literatures.

Ruth Kinna

Loughborough University, Loughborough,

Leicester, UK

\title{
Territory, authority, rights: From medieval to global assemblages
}

\author{
Saskia Sassen \\ Princeton University Press, Princeton, 2006, 493pp., £14.95 paperback, \\ $£ 29.95$ handback; ISBN: 0691095388/978-0 691095387
}

Contemporary Political Theory (2009) 8, 244-248. doi:10.1057/cpt.2008.51

This is primarily a book about globalization, though it also includes an extensive discussion of the historical emergence of the nation-state, making an argument for parallels with the present. Rather than seeing globalization as the decline of the nation-state, Sassen interprets globalization as enacted through changes within the state itself, including the emergence of technical ministries, strengthening of executives and redefinition of state functions. The global is embedded and imbricated in the local and national by means 